\title{
A Reflective, Processed-Kaolin Particle Film Affects Fruit Temperature, Radiation Reflection, and Solar Injury in Apple
}

\author{
D. Michael Glenn ${ }^{1}$ \\ U.S. Department of Agriculture, Agricultural Research Service, Appalachian Fruit Research Station, 45 \\ Wiltshire Road, Kearneysville, WV 25430 \\ Ernesto Prado ${ }^{2}$ \\ Instituto de Investigaciones Agropecuarias Centro regional de Investigacion, Casilla 439-3, Santiago, \\ Chile
}

Amnon Erez
Institute of Horticulture, ARO Volcani Center, Box 6, Bet Dagan, Israel 50250
James McFerson
Washington Tree Fruit Research Commission, 1719 Springwater Ave., Wenatchee, WA 98801

Gary J. Puterka ${ }^{2}$

U.S. Department of Agriculture, Agricultural Research Service, Appalachian Fruit Research Station, 45 Wiltshire Road, Kearneysville, WV 25430

\begin{abstract}
AdDitional INDEX wORDS. Malus sylvestris var. domestica, heat stress, fruit quality, fruit temperature, sunburn, ultraviolet radiation, infrared radiation

Abstract. Particle film technology is a new tool for tree fruit production systems. Trials were performed in Santiago, Chile, and Washington and West Virginia to evaluate the effect of particle film treatments on apple [Malus sylvestris (L.) Mill var domestica (Borkh.) Mansf.] fruit temperature and the incidence of solar injury. Fruit surface temperature was reduced by the application of reflective particles and the amount of temperature reduction was proportional to the amount of particle residue on the fruit surface. Effective solar injury suppression was achieved with spray applications of 45 to $56 \mathrm{~kg}^{-h^{-1}}$ of a reflective, processed-kaolin particle film material in concentrations ranging from $3 \%$ to $12 \%$ in some of the locations. The timing of application to suppress solar injury was not clearly defined. The processed-kaolin particle film material was highly reflective to the ultraviolet wavelengths and this characteristic may be important in reducing solar injury to both fruit and leaves.
\end{abstract}

Solar injury (SI) of apples (Malus sylvestris var. domestica) occurs in semiarid and arid regions and the damage is increased in high density plantings (Drake et al., 1991; Parchomchuk and Meheriuk, 1996). SI develops more commonly on exposed fruit on the south and west sides of tree rows ( Khemira et al. , 1993). The cause of SI is primarily excessive heat damage (Drake et al., 1991; Parchomchuk and Meheriuk, 1996); however, research in other crops suggests that ultraviolet (UV) radiation may also contribute to SI. Lipton (1977) demonstrated that near UV directly induced SI in cantaloupes [Cucumismelo L. (Cantalupensis Group)] and Renquist et al.(1989) found that SI in raspberry (Rubusidaeus L.) was directly proportional to UV-B dosage when exposed to air temperature of 42 ${ }^{\circ} \mathrm{C}$. In contrast, Lipton et al. (1987) found that UV radiation had minimal effect on SI in 'Honey Dew' melons [Cucumis melo L. (Inodorus Group)]. Adegoroye and Jolliffe (1983) suggested that SI in tomatoes (Lycopersicon esculentum Mill.) was due primarily to infrared (IR) radiation and that visible and UV radiation did not have an essential role in SI.

UV radiation is required for synthesis of anthocyanin in apple (Arakawa et al., 1985; Fan and Mattheis, 1998). However, excessive environmental UV may be harmful to the plant (Caldwell, 1981).

Received for publication 27 Apr. 2001. Accepted for publication 20 Nov. 2001 The authors wish to thank the Washington State Tree Fruit Research Commission and the Engelhard Corporation for financial support of this research.

'Soil scientist; e-mail: mglenn@afrs.ars.usda.gov.

${ }^{2}$ Entomologist.

${ }^{3}$ Horticulturist.
Renquist et al. (1989) indicated that attenuating UV absorption alone, without lowering temperature, would likely protect raspberries from SI in the field. Rabinowitch et al. (1974) demonstrated that visible light was necessary, in addition to heat, for development of SI in tomatoes; however, heat conditioning could minimize SI in tomato, cucumber (Cucumis sativus L.) and pepper (Capsicum annиит L. var. anпиит) when acquired under diurnal temperature changes (Kedar et al. 1975; Rabinowitch et al. 1986). Lighter, more reflective fruit are less prone to SI (Barber and Sharpe, 1971) and Rabinowitch et al. (1983) concluded that chlorophyll was necessary for SI development because fruit in stages of chlorophyll degradation are more susceptible to photooxidative processes.

Evaporative cooling is an effective means of cooling apple fruit and reducing SI (Parchomchuk and Meheriuk, 1996; Unrath and Sneed, 1974). Unrath and Sneed (1974) reduced fruit temperature an average of $5.6^{\circ} \mathrm{C}$ and Parchomchuk and Meheriuk (1996) reduced fruit temperature $8.1{ }^{\circ} \mathrm{C}$ in comparison to non-evaporative cooled fruit. Row covers are also an effective means of reducing fruit temperature and SI in row crops (Roberts and Anderson, 1994), but are not likely economical in tree fruit production unless used for hail protection. Lipton and Matoba (1971) used a whitewash material to reduce the surface temperature of 'Crenshaw' melons (Cucumis melo, L.) by $8{ }^{\circ} \mathrm{C}$ and suppress SI damage. Lipton (1972) also demonstrated that a whitewash material reduced net heat gain of large fruit on a daily basis. Lipton and O'Grady (1980) concluded that high temperature and UV radiation contribute jointly to SI in 'Crenshaw' melons. Application of reflec- 
tive materials to tree fruit is likely a more cost-effective and water-saving practice than evaporative cooling (Parchomchuk and Meheriuk, 1996) in reducing SI. Therefore, our primary objective was to evaluate a reflective, kaolin-based particle film material in reducing SI in apples. We evaluated temperature reduction and UV reflection on the fruit surface and field efficacy in SI reduction.

\section{Methods and Materials}

Fruit SURFace temperature studies, Kearneysville, W.VA. 'Dixie Red Delicious' spur apple on Malling 26 rootstock were planted in 1997 in rows spaced $3 \mathrm{~m}$ with $3 \mathrm{~m}$ tree spacing. In August 1999, five treatments were imposed in a randomized complete block design with six single tree replications: nontreated control, Surround WP Crop Protectant (Engelhard, Corp. Iselin, N.J.) applied in $950 \mathrm{~L}$ of water at either two, three, or four times at the rate of 56 $\mathrm{kg} \cdot \mathrm{ha}^{-1}$, and titanium dioxide applied to selected limbs. Surround WP Crop Protectant is a highly reflective processed-kaolin particle film material. All treatments were applied 5 Aug. with an airblast sprayer. Each application was allowed to dry before the next application. Nontarget trees were shielded with a tarp during treatment application. Pure titanium dioxide $\left(\mathrm{TiO}_{2}\right)$ was applied to 10 fruit on trees selected for this treatment. The $\mathrm{TiO}_{2}(6 \% \mathrm{w} / \mathrm{v})$ had the same sticker used in Surround WP(D-22, Engelhard Corp.) and was applied four times with a hand pump sprayer, allowing time for drying between each application.

Fruit surface temperature was measured with copper-constantan thermocouples. Each selected fruit had a southern exposure with minimal or no shading from the east or west. Branches were pruned away to insure solar exposure from at least 0900 to $1500 \mathrm{HR}$. Each treatment tree had 10 selected fruit and a single thermocouple was installed on the southern apex of the fruit near the stem end. The thermocouple was installed directly beneath the epidermis and forced 3 to $5 \mathrm{~mm}$ along the interface of the epidermis and the cortex of the fruit to place it away from the entry wound. The 10 thermocouples were joined in parallel to a datalogger cable. In this arrangement, the average temperature of the 10 fruit was recorded. In addition, air temperature at a $2 \mathrm{~m}$ height was measured within the canopy of a single tree with a shaded thermocouple. Temperature data were collected 6 to 11 Aug. 1999.

The amount of surface residue on each fruit was measured by washing each fruit with $\approx 100 \mathrm{~mL}$ of deionized water and collecting the wash water in a preweighed container, followed by evaporating the water and weighing the dried residue. The surface area of the fruit was estimated from a sphere using the average of the fruit height and width as spherical diameter. The amount of surface residue on the fruit in a plot was calculated as micrograms of residue per square centimeter. Control (nontreated) fruit were washed similarly and their average residue was subtracted from that calculated for treated fruit.

Maximum daily fruit temperature data were analyzed using repeated measures analysis of variance (ANOVA). The amount of residue on fruit was analyzed by ANOVA in a randomized complete block design. Linear regression analysis related maximum fruit surface temperature to fruit residue and ANOVA evaluated treatment effects for individual sampling dates.

Fruit surface temperature studies, Finley, Wash. Fruit surface temperatures were measured during September 1999 in a 6year-old 'Scarlet Delicious' orchard, planted $1.5 \times 3 \mathrm{~m}$, and in a 5year-old 'Fuji' orchard, planted $1.5 \times 3 \mathrm{~m}$. The treatments, experimental design, data analysis, installation of thermocouples, and estimation of fruit surface residues were the same as the Kearneysville study. All treatments were applied with a hand pump sprayer to fruit only. Fruit surface temperatures of 'Scarlet Delicious' were measured 21 to 22 Aug., while those of 'Fuji' apples were measured 24 to $26 \mathrm{Aug}$. Adjacent to the study areas, apples were treated with overtree evaporative cooling (EC) applied at $\approx 6 \mathrm{~mm}$ of water $/ \mathrm{h}$. Within the EC area, six trees were randomly selected and 10 thermocouples per tree were installed to measure fruit surface temperature as described previously. A $95 \%$ confidence interval was calculated as a measure of experimental error.

INFRAREDTHERMOGRAPHY OF APPLEFRUIT SURFACES, KEARNEYSVILLE. Thermal infrared images of fruit were made on two dates using a model 760 Inframetrics thermal IR video imagery system (Inframetrics, Inc. Billerica, Mass.). Two adjacent fruit each on 'Stayman' and 'Dixie Red Delicious' trees were selected that had a southern exposure and no shading from the east or west. One fruit of each cultivar was hand sprayed with $6 \%$ (w/v) Surround-WP and the other was nontreated and protected while Surround-WP was applied. On 3 Aug. 1999 'Stayman' was treated and on 17 Aug. 'Dixie Red Delicious' was treated. Both treatments were applied before $0900 \mathrm{HR}$ and image collection began at 1000 and ended at $1700 \mathrm{HR}$ on the day of application. The thermal image was adjusted so that there was usually a $20{ }^{\circ} \mathrm{C}$ span represented by colors from black to white. Inframetrics software was used to calculate mean fruit surface temperature and maximum temperature. The amount of residue on each treated fruit was estimated as described previously. The thermal emissivity of Surround-WP was equivalent to plant tissue (data not presented).

RAdiation REFLECTION STUdies, FinLeY. The reflection spectra of treated and nontreated 'Fuji' and 'Scarlet Delicious' apples described previously at Finley. were measured with a Unisys spectrometer (PP Systems, Inc., Haverville, Mass.). Reflected radiation from 195 to $400 \mathrm{~nm}$ were measured near solar noon. Ten apples per tree were measured. The fiber optic light guide was placed $5 \mathrm{~mm}$ from the shoulder of the fruit surface and angled $\approx 30^{\circ}$ south from the vertical to avoid casting a shadow over the viewing area. Five reflection scans per tree were averaged and expressed as a percentage of the nontreated control. The residue on each treated fruit was determined as described previously. Fisher's protected LSD was calculated for selected wavelengths to compare treatments using the six single tree replicates.

Solar InJURY STUdies, FinLey. Adjacent to the studies described previously, eight $\approx 0.5$ ha blocks received triweekly applications of Surround WP from petal fall to harvest. Surround WP was applied in $\approx 1000 \mathrm{~L}$ of water at $56 \mathrm{~kg} \cdot \mathrm{ha}^{-1}$ to both the 'Scarlet Delicious' and 'Fuji' trees using an airblast sprayer. The studies were established in a randomized complete block design with four replications for each of the two cultivars. At harvest, 500 fruit from each plot were classified as 1) free of SI, 2) showing some tan or brown discoloration, or 3) showing blackened discoloration. The residue on each treated fruit was determined as described previously. Data were analyzed by ANOVA with mean separation by Fisher's protected LSD.

Solar inJury studies, Curico, ChIle. Two studies were established in Curico in 1998. In the first study, 8-year-old 'Royal Gala' and 'Braeburn' orchards, both planted $4 \times 2 \mathrm{~m}$, each received the following treatments: 1) nontreated control and 2) $56 \mathrm{~kg}$ of Surround + 0.9 L M03 surfactant (Engelhard Corp., Iselin, N.J.)/ha in spray volumes of 500,1000 , or $2000 \mathrm{~L} \cdot \mathrm{ha}^{-1}$. The treatments were applied about biweekly from petal fall to harvest to 0.2 ha plots using an airblast sprayer. Each treatment was replicated three times in a randomized complete block design. The cultivars were in separate orchards. At harvest, 50 fruit from each plot were classified as 1) no discoloration, 2) slight tan discoloration, 3) brown discoloration, or 
Table 1. Amount of surface residue and maximum daily fruit surface temperature of three apple cultivars treated with Surround WP reflective particle film at two locations (Kearneysville, W.Va., and Finley, Wash.).

\begin{tabular}{|c|c|c|c|c|c|c|c|}
\hline \multirow[b]{4}{*}{ Treatment } & \multicolumn{7}{|c|}{ Maximum fruit surface temperature $\left({ }^{\circ} \mathrm{C}\right)$} \\
\hline & \multicolumn{7}{|c|}{ 'Dixie Red Delicious' at Kearneysville } \\
\hline & \multicolumn{7}{|c|}{ Sampling date } \\
\hline & $\begin{array}{l}\text { Residue } \\
\left(\mu \mathrm{g} \cdot \mathrm{cm}^{-2}\right)\end{array}$ & 6 Aug. & 7 Aug. & 8 Aug. & 9 Aug. & 10 Aug. & 11 Aug. \\
\hline Nontreated control & $23 \mathrm{e}^{\mathrm{z}}$ & $35.9 \mathrm{a}$ & $33.6 \mathrm{a}$ & $30.6 \mathrm{a}$ & $31.9 \mathrm{a}$ & $31.7 \mathrm{a}$ & $36.9 \mathrm{a}$ \\
\hline Surround $(2 \times)$ & $562 \mathrm{~d}$ & $35.2 \mathrm{ab}$ & $32.3 \mathrm{~b}$ & $30.2 \mathrm{ab}$ & $31.1 \mathrm{ab}$ & $30.7 \mathrm{bc}$ & $36.3 \mathrm{ab}$ \\
\hline Surround $(3 \times)$ & $987 \mathrm{c}$ & $35.9 \mathrm{a}$ & $32.0 \mathrm{~b}$ & $30.2 \mathrm{ab}$ & $31.0 \mathrm{ab}$ & $30.9 \mathrm{ab}$ & $36.0 \mathrm{ab}$ \\
\hline Surround $(4 \times)$ & $2043 \mathrm{a}$ & $36.3 \mathrm{a}$ & $31.8 \mathrm{~b}$ & $30.4 \mathrm{ab}$ & $31.2 \mathrm{ab}$ & $31.3 \mathrm{ab}$ & $35.3 \mathrm{~b}$ \\
\hline Titanium dioxide & $1570 \mathrm{~b}$ & $33.9 \mathrm{~b}$ & $31.7 \mathrm{~b}$ & $30.0 \mathrm{~b}$ & $29.7 \mathrm{~b}$ & $30.0 \mathrm{c}$ & $35.2 \mathrm{~b}$ \\
\hline \multirow[t]{4}{*}{ Air temperature $\left({ }^{\circ} \mathrm{C}\right)$} & & 32.3 & 30.3 & 28.9 & 26.6 & 28.4 & 32.3 \\
\hline & \multicolumn{3}{|c|}{ 'Scarlet Delicious' at Finley } & \multicolumn{4}{|c|}{ 'Fuji' at Finley } \\
\hline & \multicolumn{7}{|c|}{ Sampling date } \\
\hline & $\begin{array}{l}\text { Residue } \\
\left(\mu \mathrm{g} \cdot \mathrm{cm}^{-2}\right)\end{array}$ & 21 Aug. & 22 Aug. & $\begin{array}{c}\text { Residue } \\
\left(\mu \mathrm{g} \cdot \mathrm{cm}^{-2}\right)\end{array}$ & 24 Aug. & 25 Aug. & 26 Aug. \\
\hline Nontreated control & $15 \mathrm{c}$ & $40.9 \mathrm{a}$ & $41.8 \mathrm{a}$ & $32 \mathrm{c}$ & $40.4 \mathrm{a}$ & $37.2 \mathrm{a}$ & $42.3 \mathrm{a}$ \\
\hline Surround $(2 \times)$ & $254 \mathrm{~b}$ & $38.1 \mathrm{~b}$ & $39.2 \mathrm{~b}$ & $159 \mathrm{~b}$ & $39.7 \mathrm{a}$ & $37.0 \mathrm{ab}$ & $40.6 \mathrm{~b}$ \\
\hline Surround (4x) & $508 \mathrm{a}$ & $36.9 \mathrm{~b}$ & $37.5 \mathrm{~b}$ & $548 \mathrm{a}$ & $38.1 \mathrm{~b}$ & $35.8 \mathrm{c}$ & $38.8 \mathrm{c}$ \\
\hline Titanium dioxide & $759 \mathrm{a}$ & $37.1 \mathrm{~b}$ & $37.7 \mathrm{~b}$ & $511 \mathrm{a}$ & $38.6 \mathrm{~b}$ & $36.0 \mathrm{bc}$ & $39.2 \mathrm{c}$ \\
\hline Evaporatively cooled $\pm \mathrm{CI}^{\mathrm{y}}$ & & $32.8 \pm 2.1$ & $36.9 \pm 2.4$ & & $35.4 \pm 1.2$ & $36.3 \pm 1.1$ & $38.1 \pm 1.2$ \\
\hline Air temperature $\left({ }^{\circ} \mathrm{C}\right)$ & & 30.0 & 31.1 & & 34.8 & 32.8 & 28.1 \\
\hline
\end{tabular}

${ }^{\mathrm{z}}$ Mean separation $(\mathrm{n}=6)$ within columns and cultivars by Fisher's protected LSD at $P \leq 0.05$.

${ }^{\mathrm{y}}$ Mean temperature $\pm 95 \%$ confidence interval.

4) blackened discoloration on their surface. In the second study, 8year-old 'Royal Gala' and 'Imperial Gala' orchards, both planted 4 $\times 2 \mathrm{~m}$ received the following treatments: 1) nontreated control, 2) 56 $\mathrm{kg}$ Surround $(6 \% \mathrm{w} / \mathrm{v})$ applied in $\left.1000 \mathrm{~L} \cdot \mathrm{ha}^{-1}\right)+\mathrm{M} 03$ at $0.9 \mathrm{~L} \cdot \mathrm{ha}^{-1}$ applied three consecutive weeks from green tip to early bloom, then biweekly to harvest, 3) 6\% Surround + M03 applied three consecutive weeks following petal drop, then biweekly to harvest, 4) $6 \%$ Surround + M03 applied at petal fall followed by 2 weekly applications of 3\% Surround + M03 at $0.45 \mathrm{~L} \cdot \mathrm{ha}^{-1}$ and then biweekly 3\% applications of Surround + M03 to harvest, 5) 6\% Surround + M03 applied four consecutive weeks following petal drop, then monthly to harvest, and 6) 6\% Surround + M03 applied three consecutive weeks 30 days after petal drop, then biweekly to harvest. The treatments were applied with a handgun sprayer. Each plot had six

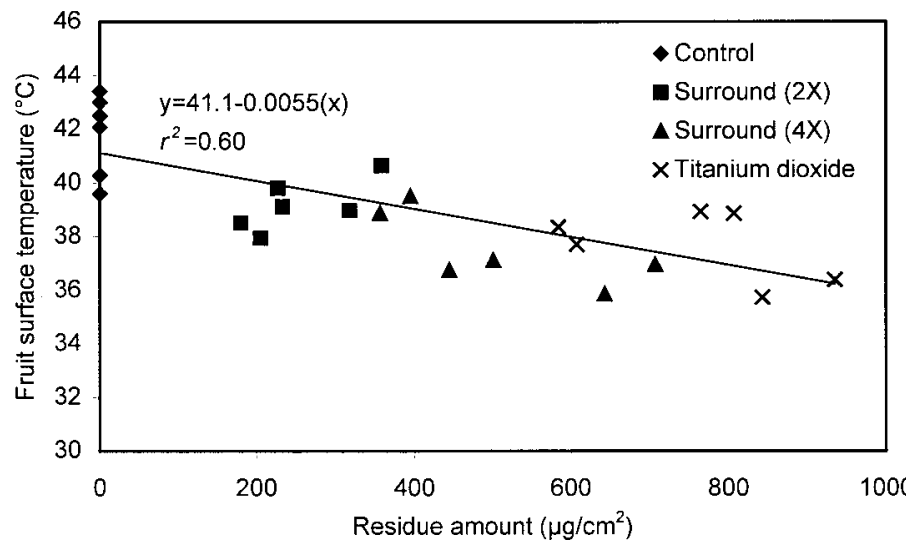

Fig. 1. Relationship between the amount of particle film residue on the apple surface and the maximum fruit surface temperature for 'Scarlet Delicious' apple on 22 Aug. 1999 at Finley, Wash. Each symbol represents the mean of 10 fruit. trees arranged in a randomized complete block design with three replications per treatment. The cultivars were in separate orchards. At harvest, 50 fruit from each plot were classified as 1) no discoloration, 2) slight tan discoloration, 3) brown discoloration, or 4) blackened discoloration on their surface. Data were analyzed using ANOVA with mean separation by Fisher's protected LSD.

Solar injury studies, La Platina, Chile. A 6-year-old 'Royal Gala' orchard, planted $3 \times 1 \mathrm{~m}$, received the following treatments: 1) nontreated control, 2) $45 \mathrm{~kg}$ of Surround $+0.7 \mathrm{~L} \mathrm{MO} 3 / \mathrm{ha}$ surfactant in spray volumes of 750 or $1500 \mathrm{~L} \cdot \mathrm{ha}^{-1}$. The treatments were applied about biweekly from petal fall to harvest to $0.2 \mathrm{ha}$ plots using an airblast sprayer. Each treatment was replicated three times in a randomized complete block design. At harvest, 60 fruit from each plot were classified as 1) no discoloration, 2) tan discoloration, 3) brown discoloration, or 4) blackened discoloration on their surface. Data were analyzed by ANOVA with mean separation by Fisher's protected LSD.

\section{Results and Discussion}

Fruit surface temperature studies. Application of Surround WP at various rates resulted in significantly different amounts of residue on fruit surfaces (Table 1). The maximum daily fruit surface temperature $\left(T_{\max }\right)$ of the nontreated control in Kearneysville was greater than the titanium dioxide treatment on all sampling dates (Table 1). Titanium dioxide is a mineral that is highly reflective of thermal IR (Blakey and Hall, 1988) and was chosen as a comparison to the commercial mineral particle film, Surround. On 7 and 11 Aug., the $4 \times$ Surround treatment had a lower $T_{\max }$ than the control but the $2 \times$ and $3 \times$ Surround treatments had a lower $T_{\max }$ than the control only on $7 \mathrm{Aug}$. On all dates, the $\mathrm{T}_{\max }$ was greater than the maximum daily air temperature as demonstrated by Schroeder 

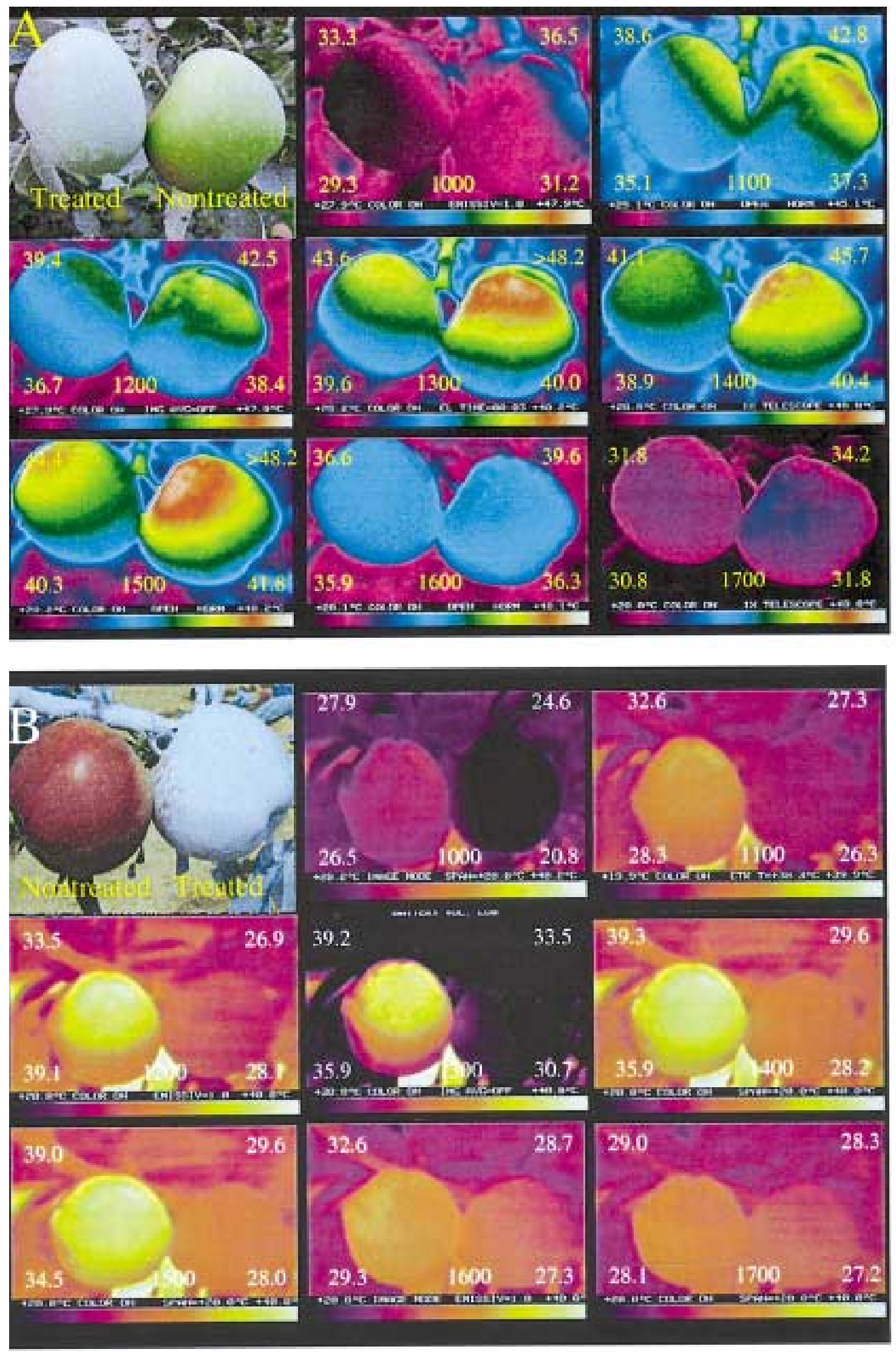

Fig. 2. Thermal infrared images of (A) 'Stayman' and (B) 'Dixie Red Delicious' with and without a reflective particle film. Each thermal frame indicates the maximum fruit surface temperature $\left({ }^{\circ} \mathrm{C}\right.$ ) above the fruit and the average fruit surface temperature $\left({ }^{\circ} \mathrm{C}\right.$ ) below the fruit. The approximate time of day (HR) is located in the bottom, middle of each frame and the color bar at the bottom indicates the associated temperature. 

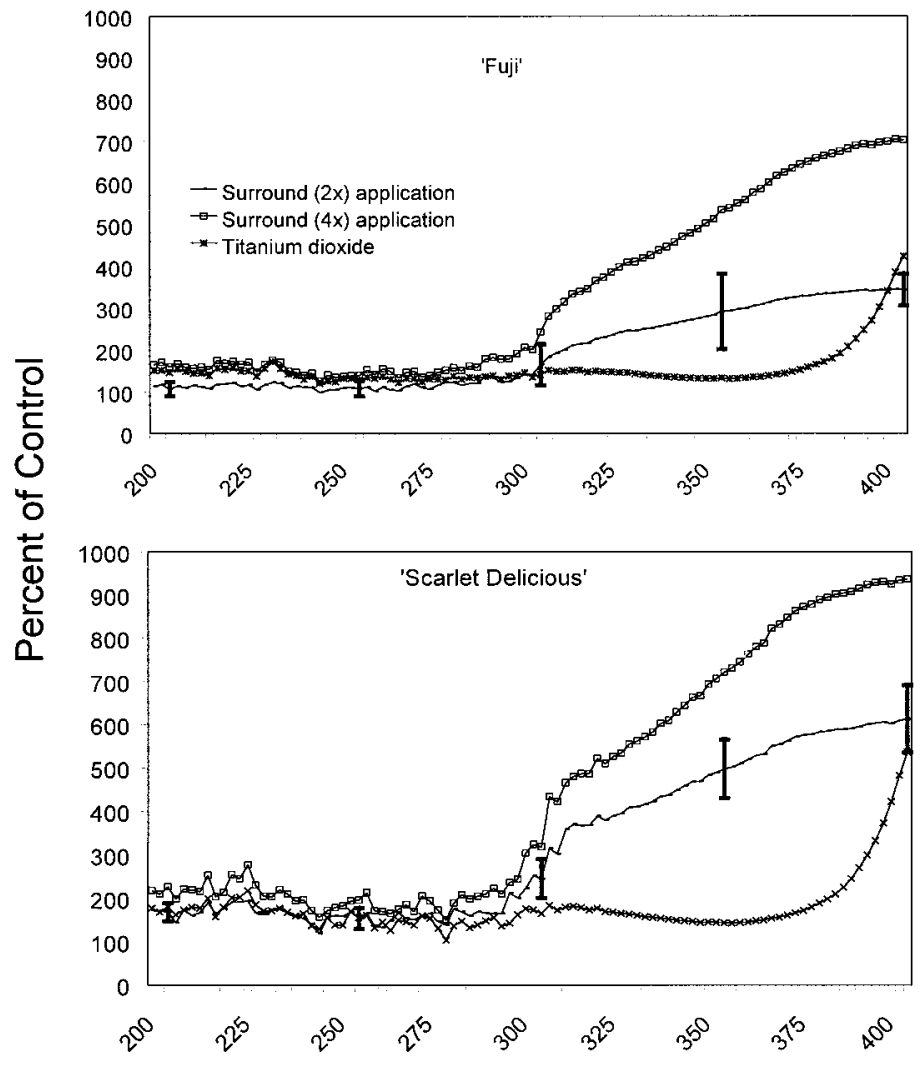

Wavelength $(\mathrm{nm})$

Fig. 3. Ultraviolet radiation reflection spectra from 'Fuji' and 'Scarlet Delicious' apples in Finley, Wash. The vertical bars represent the LSD, $P \leq 0.05$. Each symbol represents the mean of 60 fruit.

(1965) and Thorpe (1974). Surround treatments were equivalent in their reduction of $T_{\max }$ to titanium dioxide on four of the seven sampling days, but on $3 \mathrm{~d}$, the titanium dioxide treatment had the lowest $\mathrm{T}_{\max }$.

The $\mathrm{T}_{\max }$ of the nontreated control for both 'Scarlet Delicious' and 'Fuji' in Finley was greater than the $\mathrm{T}_{\max }$ of the titanium dioxide, $4 \times$ Surround, and EC treatments. The $2 \times$ Surround treatment had a lower $_{\text {max }}$ than the control on 21 and 22 Aug. for 'Scarlet Delicious' and on 26 Aug. for 'Fuji'. On all dates, $T_{\max }$ was greater than the maximum daily air temperature. $T$ he $T_{\text {max }}$ of titanium dioxide and $4 \times$ Surround were equivalent at the Finley site for both cultivars. The amount of residue appeared to be the principal factor reducing $\mathrm{T}_{\max }$ on any single day. There was no significant difference in the relationship between the fruit surface temperature and the amount of residue for Surround or $\mathrm{TiO}_{2}$ (Fig. 1; data for all sampling dates are not presented). EC treated trees appeared to be cooler than Surround treated trees on 21 Aug. in 'Scarlet Delicious' and on 24 Aug. for 'Fuji'; however, on other sampling dates, the EC maximum fruit temperature approximated the Surround $(4 \times)$ treatment.

INFRARED THERMOGRAPHY OF APPLE FRUIT SURFACES. Infrared images of the fruit in Kearneysville indicated that beginning in midmorning, the reflective particle film Surround treatment had lower fruit surface temperatures than the nontreated fruit and this temperature difference continued throughout the day (Fig. 2A and B). A zone of heating developed in the upper hemisphere of the fruit due to the radiant heating of the sun and the zone of heating rotated from the east side of the fruit to the west side (right to left in Fig. 2) through the day. In the 17 Aug. series of images (Fig. 2A), the maximum temperature of the Surround-treated fruit at $1300 \mathrm{HR}$ was $4.4{ }^{\circ} \mathrm{C}$ cooler than the nontreated fruit in the region of maximal heating on the fruit surface. The maximum air temperature was 33.6 ${ }^{\circ} \mathrm{C}$ on 17 Aug and $847 \mu \mathrm{g} \cdot \mathrm{cm}^{-2}$ of residue was present on Surroundtreated fruit surfaces. In the 3 Sept. series of images (Fig. 2B) the maximum temperature of the Surround-treated fruit was $9.7^{\circ} \mathrm{C}$ cooler than the nontreated fruit in the region of maximal heating at $1400 \mathrm{HR}$. The maximum air temperature was $30.8^{\circ} \mathrm{C}$ on 3 Sept. and $3046 \mu \mathrm{g} \cdot \mathrm{cm}^{-2}$ of residue were present on Surround-treated fruit surfaces. The reduction of fruit surface temperature was greater on 3 Sept. despite a lower maximum air temperature due to more residue on the fruit surface.

Use of infrared thermal imagery to evaluate radiant energy effects on plant surfaces is a more satisfactory method than are thermocouples. A single thermocouple in a fruit will detect maximal heating for only a brief period of time, when the fruit surface at the thermocouple is oriented normal to the irradiance. In addition, infrared thermal imagery measures the actual surface temperature rather than the temperature $\approx 1 \mathrm{~mm}$ below the surface. At 1600 and $1700 \mathrm{HR}$ (Fig. 2A), the temperature difference between the two fruit was minimal because clouds diffused the solar radiant energy. During this period of time, the fruit surface temperatures become approximately isothermal with air temperature; demonstrating that 1) it is the direct, radiant thermal IR radiation, that is reflected by the particle film, and 2) emissivity of the particle film is equivalent to the emissivity of plant material.

Radiation reflection studies, Finley. Radiation reflection data are expressed as a percentage of the control reflection spectrum (Fig. 3). Values of $100 \%$ are equivalent to the reflection spectra of the control treatment and values $>100 \%$ represent increased reflection relative to the control. All three treatments increased UV reflection (Fig. 3). In the UV-A range (320 to $400 \mathrm{~nm}$ ), the kaolinbased Surround material reflected more radiant energy than the titanium dioxide. Titanium dioxide is used as a sunscreen because it absorbs UV-A (Blakey and Hall, 1988). The $4 \times$ Surround treatment reflected more UV than the $2 \times$ Surround treatment. The reflection spectra of the $2 \times$ Surround treatment on 'Fuji' was not different from the control in the UV-B (280 to $320 \mathrm{~nm}$ ) and UV-C (200 to $280 \mathrm{~nm}$ ) regions. The reduced reflection of UV-B and UVC radiation by Surround on 'Fuji' was likely due to less particle film residue (Table 1) compared to the residue on 'Scarlet Delicious' residue treated $2 \times$ with Surround. While a direct relationship between UV radiation and solar injury in apples has not been established, we demonstrated that this particle film reduced UV penetration to the plant surface and, therefore, could reduce UV damage to other plant tissues (Caldwell, 1981).

Table 2. Incidence of solar injury of two apple cultivars treated with Surround WP reflective particle film applied at three concentrations (Curico, Chile).

\begin{tabular}{lcc}
\hline \hline & \multicolumn{2}{c}{ Solar injury (\%) } \\
\hline Treatment & 'Royal Gala' & 'Braeburn' \\
\hline Non treated control & $38 \mathrm{a}^{\mathrm{z}}$ & $68 \mathrm{a}$ \\
Surround (3\%) & $22 \mathrm{a}$ & $34 \mathrm{~b}$ \\
Surround (6\%) & $42 \mathrm{a}$ & $29 \mathrm{~b}$ \\
Surround (12\%) & $26 \mathrm{a}$ & $38 \mathrm{~b}$ \\
Linear & NS & $P<0.05$ \\
Quadratic & NS & $P<0.05$
\end{tabular}

$\overline{{ }^{\mathrm{z}} \text { Mean separation }(\mathrm{n}=3) \text { within columns and cultivars by Fisher's }}$ protected LSD at $P \leq 0.05$.

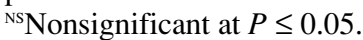


Table 3. Incidence of solar injury of two apple cultivars treated with Surround WP reflective particle film applied at various times of the year (Curico, Chile).

\begin{tabular}{lcc}
\hline \hline & \multicolumn{2}{c}{ Solar injury $(\%)$} \\
\cline { 2 - 3 } Treatment & 'Royal Gala' & 'Imperial Gala' \\
\hline Nontreated control & $33 \mathrm{a}^{\mathrm{u}}$ & $35 \mathrm{a}$ \\
Surround $^{\mathrm{z}}$ & $27 \mathrm{ab}$ & $18 \mathrm{~b}$ \\
Surround $^{\mathrm{y}}$ & $17 \mathrm{~b}$ & $25 \mathrm{ab}$ \\
Surround $^{\mathrm{x}}$ & $20 \mathrm{~b}$ & $29 \mathrm{ab}$ \\
Surround $^{\mathrm{w}}$ & $23 \mathrm{ab}$ & $23 \mathrm{ab}$ \\
Surround $^{\mathrm{v}}$ & $20 \mathrm{~b}$ & $25 \mathrm{ab}$
\end{tabular}

${ }^{\mathrm{z}}$ Surround at $6 \%$ applied at $56 \mathrm{~kg} \cdot \mathrm{ha}^{-1}$ in $1000 \mathrm{~L}+\mathrm{M} 03$ at $0.9 \mathrm{~L} \cdot \mathrm{ha}^{-1}$ applied 3 consecutive weeks from green tip to early bloom, then biweekly to harvest.

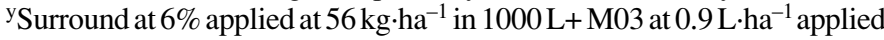
three consecutive weeks following petal drop, then biweekly to harvest. ${ }^{\mathrm{x}}$ Surround at $6 \%$ applied at $56 \mathrm{~kg} \cdot \mathrm{ha}^{-1}$ in $1000 \mathrm{~L}+\mathrm{M} 03$ at $0.9 \mathrm{~L} \cdot \mathrm{ha}^{-1}$ applied at petal fall followed by two weekly applications of 3\% Surround + M03 and then biweekly $3 \%$ applications of Surround + M03 to harvest.

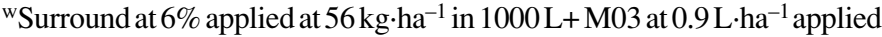
four consecutive weeks following petal drop, then monthly to harvest.

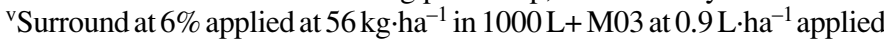
3 consecutive weeks $30 \mathrm{~d}$ after petal drop, then biweekly to harvest.

uMean separation $(\mathrm{n}=3)$ within columns by Fisher's protected LSD at $P \leq 0.05$.

Solar InJURY STUdIES. No SI occurred in the Kearneysville studies in 1999 (data not presented) and only a low incidence of SI occurred in Washington. Application of Surround WP every 3 weeks in Finley reduced SI in 'Fuji' from $11 \%$ in the nontreated control to $2 \%(P=0.05, \mathrm{n}=4)$ and from $8 \%$ in nontreated 'Scarlet Delicious' to $4 \%(P=0.05, \mathrm{n}=4)$. 'Fuji' and 'Scarlet Delicious' had 218 and $283 \mu \mathrm{g} \cdot \mathrm{cm}^{-2}$ of surface residue, respectively. Based on grower evaluations, the area of the orchard receiving EC had $<1 \%$ solar injury. The field trials in Chile had more SI incidence than Washington.

In Curico, SI to 'Royal Gala' was not affected significantly by the treatments applied at three concentrations (Table 2). However, at the same location, SI to 'Braeburn' was reduced by Surround applications, but there was no significant concentration effect (Table 2). In these two studies, Surround at $56 \mathrm{~kg} \cdot \mathrm{ha}^{-1}$ was applied and only the volume of water varied with treatment. The purpose of this trial was to determine if increasing the volume of water and, presumably, fruit coverage was of value, but no benefit was demonstrated. SI to 'Braeburn' may have been more severe than for 'Royal Gala' due to the more adverse environmental conditions after 'Royal Gala' harvest.

At another orchard near Curico, when Surround was applied at various times of the growing season, contradictory results were obtained (Table 3). In 'Royal Gala', all biweekly applications, except those beginning at green tip stage of bud development, significantly reduced SI. Conversely, in 'Imperial Gala', only the biweekly applications beginning at green tip reduced SI. Since Curico is an arid region, application of a particle film from green tip to harvest would accumulate the most residue on the fruit and therefore would be expected to reduce fruit surface temperature the most. Treatments beginning after green tip had fewer applications and so, likely, less residue near harvest when SI typically develops. Results with 'Imperial Gala' supported this hypothesis; however, results with 'Royal Gala' did not. We do not have an explanation for these contradictory results. At La Platina, application of Surround at $45 \mathrm{~kg} \cdot \mathrm{ha}^{-1}$ in concentrations of $3 \%$ and $6 \%(\mathrm{w} / \mathrm{v})$, reduced SI in 'Royal Gala' from $63 \%$ in the nontreated control to $45 \%$ and $42 \%$, respectively $(P=0.05, \mathrm{n}=3)$, and again confirmed that spray volume is not a limiting factor for fruit coverage.

In summary, Surround WP, a reflective particle film reduced fruit surface temperature and SI in apples under some conditions. Reduction in fruit surface temperature appeared to be related to the amount of residue on the fruit. Effective SI suppression was achieved with spray applications of Surround at 45 to $56 \mathrm{~kg} \cdot \mathrm{ha}^{-1}$ in concentrations ranging from $3 \%$ to $12 \%$. The timing of applications to suppress SI was not clearly defined. The kaolin-based Surround material was highly reflective to UV wavelengths and this characteristic may be important in reducing SI to both fruit and leaves.

\section{Literature Cited}

Adegoroye, A.S. and P.A. Jolliffe. 1983. Initiation and control of sunscald injury of tomato fruit. J. Amer. Soc. Hort. Sci. 108:23-28.

Arakawa, O., Y. Hori, and R. Ogata. 1985. Relative effectiveness and interaction of ultraviolet B, red and blue light in anthocyanin synthesis of apple fruit. Physiol. Plant. 64:323-327.

Barber, H.N. and P.J.H. Sharpe. 1971. Genetics and physiology of sunscald of fruits. Agr. Meteorol. 8:175-191.

Blakey, R.R. and J.E. Hall. 1988. Properties and economics, p. 1-42. In: Peter A. Lewis (ed.). Pigment handbook. vol. 1. John Wiley and Sons, New York.

Caldwell, M.M. 1981. Plant response to solar ultraviolet radiation, p. 170-197. In: O.L. Lange, P.S. Nobel, C.B. Osmand, and H.Ziegler (eds.). Physiological plant ecology. Springer-Verlag, Berlin.

Drake, S.R., F.E. Larsen, and S.S. Higgins. 1991. Quality and storage of 'Granny Smith' and 'Greenspur' apples on seedling, M.26, and MM.111 rootstocks. J. Amer. Soc. Hort. Sci. 116:261-264.

Fan, X. and J.P. Mattheis. 1998. Bagging 'Fuji' apples during fruit development affects color development and storage quality. HortScience 33:1235-1238.

Kedar, N., H.D. Rabinowitch, and P. Budowski. 1975. Conditioning of tomato fruit against sunscald. Scientia Hort. 3:83--87.

Khemira, H., P.B. Lombard, D. Sugar, and A.N. Azarenko. 1993. Hedgerow orientation affects canopy exposure, flowering, and fruiting of 'Anjou' pear trees. HortScience 28:984-987.

Lipton, W.J. 1972. Temperatures and net heat gain in normal and whitewashed cantaloupe fruits. J. Amer. Soc. Hort. Sci. 97:242-244.

Lipton, W.J. 1977. Ultraviolet radiation as a factor in solar injury and vein tract browning of cantaloupes. J. Amer. Soc. Hort. Sci. 102:32-36.

Lipton, W.J. and F. Matoba. 1971. Whitewashing to prevent sunburn of 'Crenshaw' melons. HortScience 6:343-345.

Lipton, W.J. and J.J. O'Grady. 1980. Solar injury of 'Crenshaw' muskmelons: The influence of ultraviolet radiation and of high tissue temperatures. Agr. Meteorol. 22:235-247.

Lipton, W.J., S.J. Peterson, and C.Y. Wang. 1987. Solar radiation influences solar yellowing, chilling injury, and ACC accumulation in 'Honey Dew' melons. J. Amer. Soc. Hort. Sci. 112:503-505.

Parchomchuk, P. and M. Meheriuk. 1996. Orchard cooling with pulsed overtree irrigation to prevent solar injury and improve fruit quality of 'Jonagold' apples. HortScience 31:802-804.

Rabinowitch, H.D., B. Ben-David, and M. Friedmann. 1986. Light is essential for sunscald induction in cucumber and pepper fruits, whereas heat conditioning provides protection. Scientia Hort. 29:21-29.

Rabinowitch, H.D., M. Friedmann, and B. Ben-David. 1983. Sunscald damage in attached and detached pepper and cucumber fruits at various stages of maturity. Scientia Hort. 19:9-18.

Rabinowitch, H.D., N. Kedar, and P. Dudowski. 1974. Induction of sunscald damage in tomatoes under natural and controlled conditions. Scientia Hort. 2:265-272.

Renquist, A.R., H.G. Hughes, and M.K. Rogoyski. 1989. Combined high temperature and ultraviolet radiation injury of red raspberry fruit. HortScience 24:597-599.

Roberts, B.W. and J.A. Anderson. 1994. Canopy shade and soil mulch affect yield and solar injury of bell pepper. HortScience 29:258-260.

Schroeder, C.A. 1965. Temperature relationships in fruit tissues under extreme conditions. Proc. Amer. Soc. Hort. Sci. 87:199-203.

Thorpe, M.R. 1974. Radiant heating of apples. J. Appl. Ecol. 11:755-760

Unrath, C.R. and R.E. Sneed. 1974. Evaporative cooling of 'Delicious' applesThe economic feasibility of reducing environmental heat stress. J. Amer. Soc. Hort. Sci. 99:372-375. 